\title{
KETIDAKMERATAAN BANTUAN LANGSUNG TUNAI DIMASA PANDEMI COVID-19 PADA MASYARAKAT KURANG MAMPU DI DESA CARAWALI KABUPATEN SIDRAP
}

\author{
Oleh: Irma Yunita', Andi Agustang² \\ ${ }^{12}$ Program Studi pendidikan Sosiologi Fakultas Ilmu Sosial dan Hukum \\ Universitas Negeri Makassar \\ Email:Irmayunita10124@gmail.com¹, andi.agustang@unm.ac.id ${ }^{2}$
}

\begin{abstract}
Abstrak
Penelitian ini bertujuan untuk mengetahui: 1) Mengapa penyaluran program bantuan langsung tunai di Desa Carawali tidak merata. 2) Bagaimana dampak ketidakmerataan bantuan langsung tunai terhadap masyarakat yang kurang mampu pada masa pandemik di Desa Carawali Kabupaten Sidrap. Jenis penelitian ini merupakan jenis penelitian kualitatif. Jumlah informan dalam penelitian ini sebanyak 10 orang yang ditentukan melalui teknik purposive sampling dengan kriteria informan adalah aparat desa, penerima BLT dan masyarakat kurang mampu yang tidak menerima BLT. Teknik pengumpulan data yang dilakukan yaitu observasi, wawancara dan dokumentasi. Teknik pengabsahan data menggunakan teknik member check. Hasil penelitian menunjukkkan bahwa: 1) Ketidakmerataan penyaluran program bantuan langsung tunai di Desa Carawali kabupaten Sidrap disebabkan oleh a) Ketidakakuratan data penerima bantuan langsung tunai b) Kurangnya keterbukaan informasi terkait BLT-dana Desa oleh pihak pemerintah desa, dan c) Tidak adanya pengaturan mekanisme pengawasan yang jelas terkait penyaluran BLT-Dana Desa 2). Dampak ketidakmerataan penyaluran program bantuan langsung tunai di Desa carawali yaitu: a) Terjadi diskriminasi antara masyarakat desa b) Adanya konflik kepentingan dan menimbulkan kecemburuan sosial antara si Penerima dan yang tidak menerima dan c) rasa kepercayaan masyarakat kepada pemerintah desa berkurang.
\end{abstract}

Kata Kunci: Ketidakmerataan, Bantuan langsung tunai, Masyarakat kurang mampu

\section{PENDAHULUAN}

Dana tunai atau bantuan langsung tunai tak bersyarat yang dilakukan pemerintah pada tahun 2008 diperuntukkan bagi masyarakat miskin agar tidak terlalu merasakan dampak dari kenaikkan harga BBM. Dasar pemerintah dalam membuat kebijakan program BLT ini adalah untuk membantu masyarakat miskin atau masyarakat yang berada pada kelompok kedua yang dengan pasti akan merasakan dampak dari kenaikkan harga BBM (Stamboel, 2013). Selain itu BLT diberlakukan sebagai kompensasi dari pemotongan subsidi bahan bakar minyak kepada penduduk miskin. Tidak adanya lagi subsidi untuk BBM pada tahun 2008 dnilai pemerintah akan 
menambah jumlah APBN dan akan terjadi defisit kas negara. Maka diari itu BLT ini dicanangkan sebagai kompensasi bagi penduduk miskin.

(Haryanti., 2019) bahwa: Pelaksanaan Penyaluran Bantuan Langsung Tunai kepada rumah tangga sasaran tersebut didasarkan pada Instruksi Presiden Republik Indonesia No.3 Tahun 2008 tanggal 14 Mei 2008 tentang Pelaksanaan Program Bantuan Langsung Tunai untuk Rumah Tangga Sasaran. Tahun 2012 pemerintah kembali menyediakan uang sebesar Rp1,8 triliun untuk 1,5 juta keluarga miskin. Besaran uang yang dibagi sejumlah Rp1,3 juta hingga Rp2,2 juta per keluarga. Ini merupakan lanjutan Program Keluarga Harapan ( $\mathrm{PKH}$ ) yang sudah dimulai pada tahun lalu yang saat itu sebesar Rp1,6 triliun untuk 1,1 juta keluarga miskin. Kebijakan itu dimaksudkan untuk mempercepat pengentasan rakyat dari kemiskinan. Menurut rencana, Program Bantuan Langsung Tunai (BLT). itu akan berlangsung hingga 2014 dengan target 3 juta keluarga miskin dengan dana Rp4,2 triliun.

Dalam Susanto,dkk. (2018) Istilah kemiskinan muncul ketika seseorang atau sekelompok orang tidak mampu mencukupi tingkat kemakmuran ekonomi yang dianggap sebagai kebutuhan minimal dari standar hidup tertentu. Kemiskinan dalam arti luas adalah keterbatasan yang disandang oleh seseorang, sebuah keluarga, sebuah komunitas atau bahkan sebuah negara yang menyebabkan ketidaknyamanan dalam kehidupan, terancamnya penegakan hak dan keadilan, terancamnya posisi tawar (bargaining) dalam pergaulan dunia, hilangnya generasi, serta suramnya masa depan bangsa dan negara. Dalam segala bidang selalu menjadi kaum tersingkir karena tidak dapat menyamakan kondisi dengan kondisi masyarakat sekitarnya. Akhir tahun 2019 tepatnya pada bulan desember, dunia dihebohkan dengan sebuah kejadian yang membuat banyak masyarakat resah yaitu dikenal dengan virus corona. Dewasa ini pemerintah daerah menghadapi pandemi besar covid-19 yang melanda Indonesia. Jumlah penduduk yang besar mencapai 270 juta tentu sangat beresiko untuk terpapar virus mematikan tersebut.

Putri (2020) bahwa "Indonesia saat ini terkena dampak pandemi virus baru, bahkan bukan hanya di Indonesia tetapi secara global diberbagai Negara telah terkena dampak yang sangat hebat dari virus ini”. World Health Organization (WHO) memberi nama virus ini yakni Coronavirus disease 2019 (Covid-19). Pandemi covid-19 ini akan berdampak secara sosial dan ekonomi di Indonesia.

Sebagai sebuah negara berkembang, Indonesia mengalami kondisi yang memiliki kompleksitas permasalahan yang lebih rumit, diantaranya adalah faktor Kesehatan hingga kompleksitas masalah ekonomi yang ditimbulkan, hal seperti ini juga membuat pemerintah mengeluarkan berbagai kebijakan dan regulasi guna menanggapi masalah tersebut, di antaranya adalah penerapan PSBB (Pembatasan Sosial Skala Besar) hingga regulasi kesehatan lainnya.

Kondisi tersebut membuat Indonesia berpikir ekstra, sebab kondisi ekonomi hampir sebagai masyarakat yang mulai mengalami dampak signifikan dari kondisi kebijakan sebagai konsekuensi dari pandemi ini. Pemerintah berupaya mengeluarkan kebijakan yang sifatnya kuratif untuk mananggapi kondisi ini selain dibidang kesehatan pada poin sebelumnya pemerintah juga memberikan bantuan langsung tunai. BLT 
sendiri bukanlah sebuah program baru, sebab program yang sejenis pernah dilakukan pada masa lampau, namun bukan dengan kondisi seperti hari ini.

Pramanik (2020) bahwa:Sejak diterapkan pertama kalinya ditahun 1990-an, program bantuan sosial pemerintah kepada masyarakat telah mengalami berbagai perubahan bentuk dan menjangkau lebih banyak penerima manfaat. Pada tahun 2005, program Bantuan Langsung Tunai (BLT) diperkenalkan untuk pertama kalinya sebagai pengganti subsidi BBM. Guna mengurangi dampak negatif dari pandemi covid-19 terhadap perekonomian, pemerintah melalui Kemensos telah menerapkan berbagai program bantuan sosial seperti: peningkatan jumlah penerima bantuan pada Program Keluarga Harapan, program bantuan non-tunai atau Program Sembako.

Pemberian bantuan sosial kepada masyarakat sebenarnya bukan hal yang baru dilakukan oleh pemerintah. Dalam kondisi adanya bencana disuatu daerah, misalnya, bantuan sosial ini kerap dilakukan oleh pemerintah pusat maupun pemerintah daerah tetapi respon masyarakat atas realisasi yang terjadi masih banyak menimbulkan kekecewaan atas penyalurannya (Rijanta,dkk. 2018). Bahkan, kegiatan rutin yang diberikan kepada masyarakat dilakukan sesuai dengan tingkat kemiskinan masyakarat sebagai penerima bantuan sosial dalam bentuk yang beragam. Di masa pandemi COVID-19, pemerintah, baik pusat maupun daerah, kelimpungan dalam penyaluran bantuan sosial kepada masyarakat.

Dalam kondisi pandemi covid-19 dan penyaluran bantuan langsung tunai disetiap desa. Mufida (2020) berpendapat bahwa "rentang kendali pintu antara pemerintah pusat dengan masyarakat masih terlalu jauh". Seharunya pemerintah daerah yang terdekat dari masyarakat diberi kewenangan kendali jangan langsung dari kementerian kepada penduduk, karena itu berbeda dampaknya, seperti yang didesa ada yang dapat dana desa, dan ada yang dapat dana kemensos, pada hal itu berbeda. Karenanya kepala desa menjadi bingung membagikannya, apakah si A dapat dana Kemensos ataukah si A dapat dana desa, karena pilihannya sangat banyak. Data yang diberikan pun tidak valid, seperti data warga yang sudah meninggal, tetapi masih terdaftar mendapatkan bantuan sosial. Selain itu ada warga yang sudah pindah rumah, tetapi KTP masih menggunakan alamat yang lama. Karena itu, Kemensos menggunakan data lama, sehingga tidak tepat sasaran kepada warga yang terdampak covid-19.

Berdasarkan hasil observasi awal penulis, proses penyaluran dana BLT ini sendiri menuai beberapa kritikan dari masyarakat seperti terjadinya ketidakmerataan, dan lain sebagainya, sehingga masyarakat merasa bahwa terjadi kesalahan dalam pendataan. Karena terdapat keluarga yang tidak mendapatkan bantuan padahal layak untuk mendapatkan bantuan tersebut. Dari observasi awal penulis di Desa Carawali terdapat 141 Kepala Keluarga yang tercatat sebagai penerima dana bantuan langsung tunai. Di atas kertas, pembagian BLT dana Desa Carawali terlihat terstruktur dan minim celah. Potensi kesalahan dalam penyaluran BLT dana desa tetap terbuka, sama seperti yang terjadi pada pemberian bantuan sosial yang lainnya. Berdasarkan hasil observasi awal penulis dengan melihat tabel data keluarga miskin penerima bantuan langsung tunai dari kantor desa Carawali.

Tabel 1.1 Jumlah Penerima BLT-Dana Desa Carawali 
Pinisi Journal Of Sociology Education Review; Vol. 1; No. 2; Juli 2021

Halaman 181-191

\begin{tabular}{|c|c|c|}
\hline No & Jenis Kelamin & Jumlah \\
\hline 1 & Laki-laki & 90 \\
\hline 2 & Perempuan & 51 \\
\hline & Total & 141 \\
\hline
\end{tabular}

Sumber: Olahan Data Desa Carawali

Berdasarkan tabel 1.1 dapat diketahui bahwa jumlah penerima bantuan langsung tunai berjenis kelamin laki-laki sebanyak 90 orang dan perempuan sebanyak 51 orang. Dari penjelasan di atas maka penulis tertarik untuk menelusuri dan mengkaji perihal ketidakmerataan bantuan langsung tunai di masa pandemi covid-19 saat ini.

\section{METODE PENELITIAN}

Jenis penelitian ini adalah kualitatif dengan pendekatan deskiptif. Dalam penelitian ini mengambil lokasi di Desa Carawali Kabupaten Sidrap. Penelitian ini memfokuskan pada ketidakmerataan bantuan langsung di desa Carawali Kabupaten Sidrap. terkait ketidakmerataan penyaluran bantuan langsung tunai dimasa pandemi Covid-19, dan untuk mengetahui dampak ketidakmerataan penyaluran bantuan langsung pada masyarakat kurang mampu dimasa pandemi Covid-19. Adapun tahaptahap penelitian yang dilakukan dalam penelitian ini secara garis besar yaitu tahap pra penelitian, tahap penelitian, dan tahap akhir. Sumber data yang digunakan yaitu sumber data primer dan sumber data sekunder. Jumlah informan sebanyak 10 orang yang dipilih menggunakan teknik purposive sampling. Teknik pengumpulan data dengan metode observasi, wawancara dan dokumentasi. Pengecekan keabsahan data menggunakan teknik member check. Teknik analisis data meliputi reduksi data, penyajian data, dan kesimpulan (Agustang, 2021).

\section{PEMBAHASAN}

\section{Ketidakmerataan Penyaluran Bantuan Langsung Tunai di Desa Carawali}

Dalam kajian ilmu sosiologi, terutama pada pandangan teori struktural fungsional yang menyatakan bahwa di dalam struktur terdapat suatu sistem yang memiliki fungsi arahnya untuk mencapai suatu tujuan tertentu. Hal tersebut diungkapkan oleh Theodorson dalam Raho (2007) bahwa perubahan yang terjadi pada salah satu bagian akan menyebabkan ketidakseimbangan dan pada gilirannya akan menciptakan perubahan pada bagian lain. Teori ini menjelaskan bahwa pada aspek penyaluran bantuan langsung tunai, yang mana bantuan langsung tunai hadir sebagai sebuah alternatif dari kondisi disfungsinya salah satu elemen dan perubahan yang terjadi. Pandemi Covid-19 memaksa hampir sebagaian besar masyarakat untuk tetap tinggal di rumah bahkan kebanyakan dari mereka terancam kehilangan pekerjaan sehingga menimbulkan sebuah masalah berupa pengangguran dan hilangnya pendapatan untuk pemenuhan kehidupan sehari-harinya.

Penelitian ini mendeskripsikan bahwa penyaluran program bantuan langsung tunai pada masa pandemi Covid-19 di Desa Carawali belum merata kepada seluruh masyarakat yang kurang mampu. Hal ini dapat diukur melalui mekanisme pendataan 
yang tidak benar dalam penetapaan rumah tangga sasaran. Serta banyaknya keluhan yang ditemukan dari masyarakat kurang mampu yang tidak terdaftar sebagai penerima bantuan langsung tunai pada masa pandemi Covid-19.

Selain ketidakuratan data dalam penyusunan rumah tangga sasaran, ketidakmerataan penyaluran bantuan langsung tunai juga terjadi akibat adanya nepotisme. Seperti halnya yang telah diungkapkan oleh salah satu masyarakat yang terdaftar sebagai penerima BLT bahwa "Sebenarnya dulu saya itu tidak terdaftar sebagai penerima bantuan langsung tunai, hal tersebut dikarenakan saya tidak memilih Kepala Desa yang saat ini menjabat. Padahal saya berfikir bahwa saya berhak dan sesuai untuk menerima BLT, hanya karena saya berbeda pilihan dan tidak memilih Kepala Desa yang saat ini menjabat saya merasa sangat tidak adil dan kecewa. Tetapi, saya memiliki seorang kerabat yang bekerja di kantor Desa dan Ia berkata bahwa nanti Ia yang mengurus saya agar bisa terdaftar dan menerima BLT tersebut. Pada akhirnya saya terdaftar dan menerima BLT- Dana Desa. Sulit bagi kami sebetulnya mendapatkan BLT jika memang tidak memiliki seorang kerabat yang bekerja di Kantor Desa”

Dari hasil penelitian tersebut, program bantuan langsung tunai diharapkan masyarakat yang kehilangan mata pencaharian sehingga berdampak pada kehidupan ekonomi mereka ini dapat membantu masyarakat miskin agar dapat bertahan hidup di masa pandemi covid -19. Sehingga masyarakat miskin tidak menjadi lebih miskin.

Penelitian ini relevan dengan pendapat (Rosfadhila,Dkk. 2011) "masyarakat miskin sudah pasrah dan putus asa setelah lama memperjuangkan BLT tetapi tidak pernah berhasil". Maka dari itu masyarakat yang kurang mampu dan tidak memiliki seorang kerabat yang bekerja di pemerintahan Desa hanya pasrah dan berharap kedepannya mereka terdaftar dan menerima bantuan langsung tunai.

Penelitian ini juga menggambarkan bantuan ini hanya bisa menambah pendapatan masyarakat dan dapat membantu dalam pemenuhan kebutuhan hidup, namun peranan tersebut relatif kecil karena jumlahnya masih kecil dan bersifat sementara. Pelaksanaan Bantuan Langsung Tunai pada masa pandemik Covid-19 di Desa Carawali ini belum maksimal, karena masyarakat yang berada di bawah garis kemiskinan dan masih banyak juga masyarakat yang membutuhkan bantuan ini, sehingga perlu diadakannya penyeleksian yang dalam hal ini dilakukan oleh Kepala Desa dan aparatnya masing-masing dengan menetapkan kebijakan penentuan kriteria sendiri karena kriteria yang ditetapkan pemerintah tidak cocok dengan data di lapangan. Di dalam penentuan kriteria tersebut, masyarakat miskin yang berhak mendapatkan BLT di masa pandemik Covid - 19 harus memenuhi syarat sebagai masyarakat miskin, seperti masyarakat yang mempunyai pekerjaan tidak tetap atau pekerja lepas pada masa pandemi, yang penghasilannya tidak mencukupi untuk biaya hidup anggota keluarganya yang banyak.

Program bantuan langsung tunai ini bersifat jangka pendek, yakni untuk memenuhi kebutuhan sehari-hari seperti sembako. Program jangka pendek maksudnya adalah bahwa program ini hanya diluncurkan pada keadaan tertentu dan sifatnya sementara, sebagaimana program bantuan langsung tunai yang diluncurkan ketika 
terjadinya kenaikan harga BBM atau krisis ekonomi dunia yang menyebabkan turunnya daya beli masyarakat miskin.

Listyaningsih (2009) mengungkapkan bahwa "bantuan langsung tunai merupakan skema pengaman sosial yang diberikan kepada kelompok-kelompok yang rentan menyusul adanya dampak-dampak negatif jangka pendek akibat diterapkannya suatu kebijakan". Program bantuan langsung tunai menyebabkan timbulnya ketidakmerataan yang terjadi di lapangan. Seperti yang telah disebutkan sebelumnya, ketidakakuratan data dan adanya nepotisme dalam penetapan penerima BLT menyebabkan beberapa masyarakat kurang mampu yang ada di Desa Carawali tidak mendapatkan hal tersebut.

Berdasarkan hasil penelitian yang telah dilakukan, penulis menemukan bahwa: pertama ketidakakuratan data dan adanya nepotisme dalam penetepan penerima bantuan langsung tunai menjadi penyebab ketidakmerataan penyaluran program BLT. Masyarakat yang memiliki hubungan keluarga atau kekerabatan dengan aparat Desa bisa dipastikan menerima bantuan langsung tunai pada ,asa pandemi ini. Dalam hal ini juga pemerintah harus dituntut menjalani aturan hukum yang telah ditetapkan mengenai penyaluran bantuan langsung tunai, karena dalam aturan tersebut menjelaskan tentang kriteria masyarakat yang berhak menerima bantuan ini. Karena sesuai aturan yang berlaku, bahwa program ini dapat dijalankan dengan baik oleh pemerintah yang ada, guna bisa menjawab permasalahan ekonomi masyarakat di tengah pandemik Covid -19 .

Adapun kerangka hukum yang adil dan dilaksanakan tanpa pandang bulu. Artinya setiap kebijakan ataupun peraturan yang telah ditetapkan harus berjalan dengan baik sesuai dengan peraturan yang ada. Dalam hal ini program Bantuan Langsung Tunai (BLT) telah ditetapkan sebagai program untuk bisa membantu para masyarakat yang terdampak Covid-19. Terutama masyarakat yang kehilangan pekerjaan, ekonomi di bawah, dan masyarakat yang sangat membutuhkan bantua.n ini dimasa pandemi Covid-19. Berdasarkan teori struktural fungsional bahwa sebuah sistem harus mendefinisikan dan mencapai tujuannya. Namun hal yang terjadi pada penyaluran BLT ini nyata tidak sesuai dengan harapan atau pun tujuan yang ada, karena banyak masyarakat yang ekonomi mampu tetapi menerima bantuan BLT, artinya dinilai tidak layak. Hal yang membuat sampai itu terjadi dikarenakan masyarakat dekat dengan aparat pemerintah ataupun pemerintah itu sendiri, sehingga pemerintah tidak lagi mengutamakan masyarakat yang sangat membutuhkan BLT ini apalagi masyarakat yang benar-benar terdampak Covid - 19 ini di bidang ekonomi.

Kedua, selain ketidakakuratan data kurangnya informasi terkait bantuan langsung tunai kepada masyarakat kurang mampu di Desa Carawali juga menjadi penyebab ketidakmerataan penyaluran program tersebut. Berkaitan dengan teori struktural fungsional bahwa tidak berfungsinya suatu elemen maka akan menyebabkan ketidakseimbangan sistem. Masyarakat kurang mampu tidak mengetahui kriteria serta pendataan rumah tangga sasaran. Biasanya informasi mengenai BLT hanya terdengar oleh tetangga mereka yang telah menerima dana BLT tersebut. Masih lemahnya sosialisasi program yang terlihat dari kurangnya penekanan penjelasan mengenai latar 
belakang dan tujuan pemberian BLT, kriteria penerima BLT. Sosialisasi materi ini amat penting untuk meminimalisasi konflik dan meningkatkan peran pengawasan dari masyarakat. Informasi mengenai program BLT terhadap masyarakat kurang mampu yang tidak memiliki hubungan keluarga dengan aparat Desa, transparansi dan partisipasi masyarakat diharapkan bisa mengurangi kecemburuan sosial, pikiran negatif kepada pemerintah Desa dan penyaluran bantuan langsung tunai menjadi adil serta tepat sasaran.

Ketiga, dalam penyaluran program bantuan langsung tunai tidak adanya pengaturan mekanisme pengawasan yang jelas juga menjadi penyebab ketidakmerataan BLT di Desa Carawali. Adanya mekanisme pengawasan penyaluran BLT-Dana Desa ini bertujuan untuk memastikan program BLT berjalan tepat sasaran dan efektif. Terdapat beberapa hal yang tidak diinginkan dan akhirnya terjadi dalam penyaluran BLT-Dana Desa, seperti contohnya kecurangan berupa pemotongan dana penerima atau tidak menerima bantuan sama sekali. Bahkan kecurangan lain yang terjadi yaitu ketika pendataan penerima bantuan, pihak pendata lebih mendahulukan kenalan mereka. Mekanisme pengawasan yang jelas terkait penyaluran bantuan langsung tunai ini penting adanya untuk mendeteksi kecurangan-kecurangan yang terjadi dalam proses penyaluran bantuan tersebut.

Terkait dengan teori yang digunakan dalam penelitian ini adalah teori struktural fungsional dari Theodorson dalam Raho (2007) memaparkan bahwa "struktural fungsional memandang masyarakat sebagai satu sistem yang terdiri dari bagian-bagian yang saling berhubungan satu sama lain apabila terjadi perubahan pada salah satu bagian akan menyebabkan ketidakseimbangan". Jika dikaitkan dengan ketidakmerataan penyaluran bantuan langsung tunai dimasa pandemi disini berkaitan dengan aspek hadirnya bantuan langsung tunai sebagai sebuah alternatif dari kondisi disfungsinya salah satu elemen dan perubahan yang terjadi. Perubahan yang dimaksud ialah pada masa pandemi Covid-19 ini. Akan tetapi perubahan tersebut juga menyebabkan ketidakseimbangan pada sistem yang berlaku di masyarakat. Demikian halnya, dimasa pandemi ini yang menyebabkan banyak masyarakat untuk tetap tinggal di rumah bahkan terkena PHK sebagai dampak dari adanya Covid-19. Hadirnya program bantuan langsung tunai yang diperadakan oleh pemerintah diharapkan bisa membantu masyarakat yang terkena dampak pandemi Covid-19. Akan tetapi yang terjadi di lapangan, proses penyaluran bantuan langsung tunai di Desa Carawali hingga saat ini masih belum merata kepada seluruh masyarakat yang terkena dampak.

Hasil penelitian yang ditemukan berbeda dengan penelitian terdahulu yang dilakukan oleh Suryani (2010) dengan judul "Peranan Dana Bantuan Langsung Tunai (BLT) Dalam Upaya Membantu Perekonomian Masyarakat Menurut Perspektif Ekonomi Islam Di Desa Sungai Sarik Kecamatan Kampar Kiri Kabupaten Kampar”. Pada penelitian yang dilakukan oleh suryani mengungkapkan bahwa penyaluran bantuan langsung tunai diberikan kepada masyarakat yang terdaftar dan tidak terdaftar sebagai penerima BLT. Hal tersebut didasarkan pada kebijakan pemerintah desa 
setempat yang memberikan sebagian dana bantuan langsung tunai kepada masyarakat miskin yang tidak terdaftar sebagai penerima BLT-Dana Desa Sungai Sarik.

Adapun keterkaitan penelitian ini dengan penelitian terdahulu yaitu pada penelitian yang dilakukan oleh Harwidiansyah (2011) dengan judul "Dampak Bantuan Langsung Tunai terhadap Kesejahteraan Masyarakat Desa Maccini Baji Kecamatan Bajeng Kabupaten Gowa” yang menjadi persamaan pada penelitian ini yaitu terletak pada program bantuan pemerintah yang diberikan kepada masyarakat kurang mampu. Pada penelitian yang dilakukan sebelumnya yaitu dampak bantuan langsung tunai membantu masyarakat Desa yang ada di Maccini Baji dalam hal perekonomian sedangkan pada penelitian yang dilakukan oleh penulis adalah dampak ketidakmerataan bantuan langsung tunai pada masa pandemic Covid-19. Perbedaan selanjutnya terletak pada lokasi dan fokus penelitian, pada penelitian sebelumnya lokasi dan fokus penelitian dilakukan di Desa Maccini baji yang membahas tentang dampak bantuan langsung tunai terhadap kesejahteraan masyarakat di Desa tersebut. Sedangkan penelitian ini dilakukan di Desa Carawali yang membahas tentang ketidakmerataan penyaluran program bantuan langsung tunai pada masyarakat kurang mampu dimasa Covid-19.

\section{Dampak Ketidakmerataan Bantuan Langsung Tunai Pada Masa Pandemi di Desa Carawali.}

Dalam perspektif fungsional struktural, struktur sosial dan pranata sosial tersebut berada dalam sistem sosial yang terdiri atas elemen-elemen ataupun bagianbagian yang saling menyatu dan mempunyai keterkaiatan dalam keseimbangan. Fungsional struktural menekankan keteraturan dan mengabaikan konflik serta perubahan-perubahan yang terjadi pada masyarakat (Maunah, 2016). Struktural fungsional menekankan pada peran dan fungsi struktur sosial yang menitik beratkan konsensus dalam masyarakat. Pemberian bantuan langsung tunai ini perlu mendapatkan perhatian sehingga bantuan ini mampu memberikan manfaat, untuk itu peran dari setiap elemen sangat penting dalam memainkan fungsinya dalam pemberian bantuan tersebut terlebih di tengah pandemi seperti saat ini. Berdasarkan hasil penelitian yang ditemukan bahwa dampak ketidakmerataan bantuan langsung tunai pada masa pandemi Covid-19 yaitu:

Pertama, terjadinya diskriminasi antar masyarakat desa. Dalam proses penyaluran bantuan langsung tunai di Desa Carawali terindikasi pilih kasih. Sampai saat ini masih banyak masyarakat kurang mampu yang seharusnya mendapatkan BLT, tetapi tidak mendapatkan bantuan tersebut. Hirawan (2020) mengungkapkan bahwa "distribusi bantuan langsung tunai kepada masayarakat kurang optimal karena ketidaksiapan pemerintah desa serta belum siapnya sistem pendukung keputusan untuk menentukan keluarga miskin mana yang seharusnya diberikan bantuan.” Berkaitan dengan teori struktural fungsional bahwa teori ini mengutamakan bagaimana berfungsinya setiap struktur atau elemen yang saling berkaitan. Sebagaimana yang 
disebutkan dalam teori struktural fungsional bahwa perubahan yang terjadi pada satu bagian akan membawa perubahan terhadap bagian yang lain. Hal tersebut sejalan dengan apa yang didapatkan dari hasil wawancara yang dilakukan oleh penulis, Penyaluran BLT yang tidak tepat sasaran memunculkan konflik sebagian besar berupa ketegangan, baik antara si penerima dan non-penerima, maupun antara non-penerima dan aparat pemerintah Desa. Ketegangan tersebut dipicu oleh adanya komentar sinis dari non-penerima kepada si penerima, tuduhan nepotisme serta ketidakadilan aparat desa dalam penetapan sasaran penerima BLT. Komentar sinis dan tuduhan nepotisme ini muncul dari masyarakat yang merasa lebih miskin dari si Penerima tetapi tidak menerima BLT.

Mufida (2020) memandang bahwa "pemberian bantuan sosial di tengah pandemik covid-19 menimbulkan banyak polemik". Banyaknya kebijakan yang dikeluarkan terkait dengan jenis bantuan sosial menyebabkan kekisruhan dan kebingungan masyarakat akan pintu bantuan yang mereka dapat, pendataan yang tidak tepat sasaran dan jangka waktu penyaluran bantuan yang tidak serentak. Berkaitan dengan hal tersebut, hasil penelitian yang didapatkan setelah melakukan wawancara bahwa ketidakakuratan data dan adanya nepotisme dalam pendataan program bantuan langsung tunai tentunya menjadi penyebab ketidakmerataan penyaluran program bantuan tersebut. Timbulnya ketidakmerataan penyaluran bagi masyarakat yang kurang mampu telah menimbulkan dampak bagi si penerima dan yang tidak menerima bantuan tersebut. Hal tersebut menciptakan ketidakadilan bagi masyarakat kurang mampu yang harusnya terdaftar sebagai penerima bantuan langsung tunai.

Kedua, ketidakmerataan bantuan langsung tunai pada masa Covid-19 di Desa Carawali menimbulkan konflik kepentingan yang berakhir pada kecemburuan sosial. Beberapa masyarakat di Desa Carawali yang merasa terkena dampak dari pandemi pada kenyataannya tidak terdaftar dan menerima BLT, hal tersebut tentunya tentunya menjadi pemicu kecemburuan sosial bagi beberapa orang di Desa Carawali. Berkaitan dengan hal tersebut, tentunya diperlukan forum semacam musyawarah Desa untuk memutuskan bantuan yang akan diberikan, karena hal yang terpenting ialah terpenuhinya kesejahteraan untuk seluruh masyarakat di Desa Carawali yang terdampak oleh pandemi ini secara adil dan merata. Teori struktural fungsional mempunyai hubungan yang erat dengan hal tersebut. Di mana teori ini menjelaskan bahwa dalam suatu sistem jika ada yang tidak berfungsi maka akan merusak keseimbangan dalam sistem. Pemerintah Desa harusnya lebih cepat tanggap terhadap keluhan-keluhan yang dirasakan oleh masyarakat kurang mampu di Desa Carawali dan seharusnya pemerintah Desa dapat belajar dari program-program BLT yang lalu untuk meminimalisir kekurangan-kekurangan dalam penyaluran BLT-Dana Desa terutama pada masa pandemi saat ini yang membuat masyarakat lebih kesulitan perihal perekonomian.

Ketiga, rasa kepercayaan masyarakat kepada pemerintah desa berkurang. Dengan kondisi serba kesulitan terutama pada masa pandemi, adanya bantuan 
langsung tunai yang diberikan oleh pemerintah diharapkan bisa mengurangi beban dari masyarakat yang terkena dampak pandemi Covid-19. Akan tetapi yang diharapkan berbeda dengan kenyataan yang ditemukan di lapangan. Joharudin et al. (2020, h. 49) menyebutkan bahwa "kebijakan lain yang diberikan Pemerintah yakni memberikan Bantuan Langsung Tunai (BLT) untuk setiap kepala rumah tangga yang dinilai kurang mampu." Namun, pelaksanaan ini membuat terjadinya penolakan di beberapa wilayah. Bagi wilayah yang menolak, mereka beralasan memiliki kekhawatiran banyak masyarakat yang tidak tercatat sebagai penerima Bantuan Sosial ini. Teori struktural fungsional mempunyai hubungan yang erat dengan hal tersebut. Di mana teori ini menjelaskan bahwa dalam suatu sistem jika ada yang tidak berfungsi maka akan merusak keseimbangan dalam sistem. Pemerintah Desa harusnya lebih cepat tanggap terhadap keluhan-keluhan yang dirasakan oleh masyarakat kurang mampu di Desa Carawali dan seharusnya pemerintah Desa dapat belajar dari program-program BLT yang lalu untuk meminimalisir kekurangan-kekurangan dalam penyaluran BLT-Dana Desa terutama pada masa pandemi saat ini yang membuat masyarakat lebih kesulitan perihal perekonomian.

Adapun keterkaitan penelitian ini dengan penelitian terdahulu yaitu pada penelitian yang dilakukan oleh Marini (2015) dengan judul “ Dampak Penyaluran Bantuan Langsung Tunao (BLT) Terhadap Masyarakat Miskin di Desa Perawang Barat Kecamatan Tualang Kabupaten Siak". Terdapat persamaan pada penelitian terdahulu yaitu pada dampak pemberian bantuan langsung tunai pada masyarakat miskin. Pada penelitian terdahulu membahas tentang dampak bantuan langsung tunai terhadap masyarakat miskin yang menyebabkan pertikaian yang terjadi sesama masyarakat dan merasa ketidakpuasaan terhdapa proses penyaluran bantuan langsung tunai. Pada penelitian yang dilakukan oleh penulis adalah tentang dampak dari ketidakmerataan penyaluran bantuan langsung tunai di Desa Carawali yang menyebabkan timbulnya kecemburuan sosial hingga rasa kepercayaan kepada pemerintah desa berkurang.

Dari hasil di atas sudah jelas bahwa terdapat 3 dampak ketidakmerataan bantuan langsung tunai dimasa pandemi Covid-19 yaitu, terjadinya diskriminasi antar masyarakat desa, timbulnya kecemburuan sosial, dan kepercayaan masyarakat terhadap pemerintah desa berkurang.

\section{PENUTUP}

Berdasarkan hasil penelitian dan pembahasan, Ketidakmerataan penyaluran program bantuan langsung tunai pada masa pandemi Covid-19 di Desa Carawali disebabkan oleh: a) Ketidakakuratan data dan adanya nepotisme dalam penetepan penerima bantuan langsung tunai menjadi penyebab ketidakmerataan penyaluran program BLT, b) Kurangnya keterbukaan informasi seputar BLT-Dana Desa oleh pihak pemerintah desa, c) Tidak adanya pengaturan mekanisme pengawasan yang jelas terkait penyaluran BLT-Dana Desa. Adapun dampak dari ketidak merataan penyaluran program BLT tersebut yaitu: a) terjadinya diskriminasi antar masyarakat desa. Dalam 
proses penyaluran bantuan langsung tunai di Desa Carawali terindikasi pilih kasih. b) Timbulnya konflik kepentingan yang berakhir pada kecemburuan sosial, c) Kepercayaan masyarakat terhadap pemerintah berkurang.

\section{DAFTAR PUSTAKA}

Agustang, A. (2021, January 22). Filosofi Research Dalam Upaya Pengembangan Ilmu. https://doi.org/10.31219/osf.io/9n6za

Agustang, A., \& Oruh, S. (2021, January 22). Teknologi Partisipasi Metode Fasilitasi Pembuatan Keputusan Partisipatif. https://doi.org/10.31219/osf.io/dhfb7

Harwidiansyah, H. (2011). Dampak Bantuan Langsung Tunai terhadap kesejahteraan masyarakat Desa Maccini Baji Kecamatan Bajeng Kabupaten Gowa. (Doctoral Dissertation, Universitas Islam Negeri Alauddin Makassar).

Haryanti. (2019). Implementasi Bantuan Langsung Tunai (Blt) Di Kecamatan Tanjungpinang Barat Kelurahan Bukit Cermin Kota Tanjungpinang Tahun 2012. Journal of Chemical Information and Modeling, 53(9), 1689-1699.

Hirawan, F. B. (2020). Optimizing the Distribution of the Social Assistance Program during the COVID19 Pandemic. (June), 1-7.

Listyaningsih, U. and Kiswanto, E. (2009). Bantuan Langsung Tunai Mengatasi Masalah dengan Masalah. Populasi, 2O(1), Pp.13-26.

Marini, D. (2015). Dampak penyaluran bantuan langsung tunai (BLT) terhadap masyarakat miskin di Desa Perawang Barat Kecamatan Tualang Kabupaten Siak. Jurnal Online Mahasiswa Bidang Ilmu Sosial Dan Ilmu Politik, 2(1), Pp.1-10.

Maunah, B. (2016). Pendidikan dalam perspektif struktural fungsional. Cendekia: Jurnal Pendidikan Dan Pembelajaran, 10(2), Pp.159-178.

Mufida, A. (2020). Polemik Pemberian Bantuan Sosial Di Tengah Pandemic Covid 19. Buletin Hukum \& Keadilan, 4(1), 159-166.

Oruh, S., Agustang, A., \& Theresia, M. (2021, January 9). KESEJAHTERAAN PSIKOLOGIS (Studi Pada Dewasa Madya yang Belum Menikah di Kota Makassar). https://doi.org/10.31219/osf.io/v5af8

Pramanik, N. D. (2020). Dampak bantuan paket sembako dan bantuan langsung tunai terhadap kelangsungan hidup masyarakat padalarang pada masa pandemi covid 19. Jurnal Ekonomi, Sosial \& Humaniora, 1(12), Pp.113-12O.

Putri, R. N. (2020). Indonesia dalam menghadapi pandemi Covid-19. Jurnal Ilmiah Universitas Batanghari Jambi, 20 (2), Pp.705-709.

Raho, B. (2007). Teori Sosiologi Modern. Prestasi Pustaka Rosfadhila.

Rijanta, R., Hizbaron, D.R. and Baiquni, M. (2018). Modal Sosial dalam Manajemen Bencana.

Rosfadhila, M., Toyamah, N., Sulaksono, B., Devina, S., Sodo, R.J. and Syukri, M., . (2011). Kajian Cepat Pelaksanaan Program Bantuan Langsung Tunai (BLT) 2008 dan Evaluasi Penerima Program BLT 2005 di Indonesia. SMERU Research Institute, pp.1-107.

Stamboel, K. A. (2013). Panggilan Keberpihakan. Gramedia Pustaka Utama.

Susanto, E., Rochaida, E. and Ulfah, Y. (2018). Pengaruh inflasi dan pendidikan terhadap pengangguran dan kemiskinan. Inovasi, 13(1), Pp.19-27. 